\title{
Pharmacological Strategies on Medicinal Plants as Hepatoprotective Agents
}

\author{
Saurabh Nimesh ${ }^{1 *}$ and Shubham ${ }^{2}$ \\ ${ }^{1}$ Department of Pharmaceutical Technology, Meerut Institute of Engineering and Technology, Meerut, Uttar Pradesh, India \\ ${ }^{2}$ Senior Veterinary Field Manager; Vet Mankind Pharma Ltd., Haldwani Headquarter, Uttarakhand, India
}

*Corresponding Author: Saurabh Nimesh, Research Scholar; Department of Pharmaceutical Technology, Meerut Institute of Engineering and Technology, Meerut, Uttar Pradesh, India.

Received: April 25, 2019; Published: June 07, 2019

DOI: $10.31080 /$ ASPS.2019.03.0298

\begin{abstract}
Liver is a major organ or part of the human body, its play a crucial role in metabolism and excretion of xenobiotics from the body. Liver injury or disease may be a major unhealthiness in developed countries. Medicine and Pharmacognosy to develop proof based mostly employed in the treatment or cure of various types of liver disease/disorder in humans and animals. Medicinal practitioners have prescribed ayurvedic drugs from medicinal plant source in India over the centuries. Popularity of medicinal herbal drug is increasing globally. This review article describes the information on liver protective drugs; herbal drugs used as hepatoprotective agents in ayurvedic system of medicine and the ayurvedic formulations employed to cure liver disorders.
\end{abstract}

Keywords: India; Tinospora cordifolia; Livergen; Toxin; Rifampicin; Paracetamol

\section{Introduction}

The liver, is one of the vital organs found in human and animal body. In humans, it is located in the upper quadrant of the abdomen, below the diaphragm. It has a superior role in maintenance, playing and control equilibrium of the body. It involves in the majority organic chemistry pathways to growth, fight against malady, nutrient provide, energy production and replica. The liver regulates several vital metabolic functions [1-4]. Hepatic injury is related to distortion of those metabolic functions. It's exposed to xenobiotics, due to its strategic placement within the body. The toxins absorbed from the bowel tract gain access first to the liver, leads to a spread of liver ailments [5]. Thus, liver diseases stay one among the intense health issues. Trendy medicines have very little to supply for improvement in viscus malady and it's mainly the plant-based preparations that square measure utilized for the treatment of liver disorders. Natural product square measure taking part in an important role in health care for decades. Often completely different sources of natural product, plants are a supply of chemical substance, that is medication in their claim or key ingredients in formulation containing synthetic drugs [6-8]. The choice of the plant species may be a crucial issue for the final word success of investigation. Through random choice provides some hint, targeted assortment supported chemotaxonomic relationships and ethnomedical data derived from ancient drugs are additional possible to yield pharmacologically active compounds [9]. Although the advances in trendy medicines are important, there remains an ever-increasing demand for herbal medicines. Effective and potent herbal medicines need analysis by customary scientific strategies thus on be valid for the treatment of diseases. Drug induced liver toxicity is major ill health that challenges not only healthcare professionals; however, additionally the pharmaceutical trade and additionally drug regulative agencies. The inhibition of atom generation will function facile model for evaluating the activity of hepatoprotective agents [10-12].

\section{Epidemiology}

According to World Health Organization, global prevalence of liver cirrhosis ranges from $4.5 \%-9.5 \%$ of general population. Hence, estimated the $>50$ million population of the world suffer with chronic liver disease. During 2001, the estimated worldwide mortality from cirrhosis was 771000 people, ranking $14^{\text {th }}$ and $10^{\text {th }}$ 
leading cause of death in the developed countries like China, India, U.S., Australia and United Kingdom. Hepatocellular carcinoma, or a cancer in the liver, is the $2^{\text {nd }}$ most common cause of death due to malignancy in the world. The assumption of liver cirrhosis is the $12^{\text {th }}$ leading cause of deaths in 2020 [13-15].

\section{Aetiology}

Many chemicals, Drugs, house hold things, herbs and environmental chemicals have been known to induce hepatotoxicity (Table 1 and 2) [16-19].

\begin{tabular}{|c|c|c|}
\hline S. No. & Category & Agent \\
\hline 1 & $\begin{array}{c}\text { Pollutant chemical in } \\
\text { food and water }\end{array}$ & Polychlorinated biphenyls, polybrominated biphenyls, chloroalkane \\
\hline 2 & Plant extract & Pyrrolizidine alkaloids, pennyroyal, kava kava, broom corn, bajiaolian, margosa oil, jin bu huan, \\
chaparral
\end{tabular}

Table 1: Hepatotoxicity inducing agents.

\begin{tabular}{|c|c|}
\hline S. No. & Liver diseases \\
\hline 1 & Necrosis and cirrhosis \\
\hline 2 & Hepatitis- may be of viral, toxic or deficiency type \\
\hline 3 & Hepatic failure - Acute or chronic \\
\hline 4 & Disorders associated with fat (liposis) metabolism: Fatty Liver \\
\hline 5 & $\begin{array}{l}\text { Chemical/drug induced hepatotoxicity: Generally, may be hepatitis, } \\
\text { jaundice and carcinogenesis }\end{array}$ \\
\hline 6 & $\begin{array}{l}\text { Disorders associated with bilirubin metabolism: Jaundice } \\
\text { (Haemolytic jaundice, obstructive jaundice, hepatogenous jaundice }\end{array}$ \\
\hline 7 & $\begin{array}{l}\text { Hereditary jaundice or pure cholestasis: Gilbert's syndrome, Dubin Johnson syndrome, } \\
\text { Crigler-Najjar syndrome, and Rotor's syndrome }\end{array}$ \\
\hline
\end{tabular}

Table 2: Commonly observed liver problems

Sign and symptoms

Signs and symptoms of liver disease are including in figure 1 [20].

\section{Prevention}

Congenital liver diseases cannot be preventable, they're gift from birth. All which will be done is to treat symptoms as they arise. However, abundant may be done to stop disease that's the results of an infection, alcohol or misuse, and diet decisions
[21]. Vaccinations square measure offered for defence against viral hepatitis A and B. Get tested for hepatitis C Virus if you're in an at-risk population (e.g. baby boomers, veterans, healthcare/ emergency medical employees exposed to blood) and ask for treatment if necessary. Maintain a healthy diet and regular exercise program. Moderate alcohol intake and use medications as prescribed. Avoid contact with alternative people's blood and body fluids [22]. 


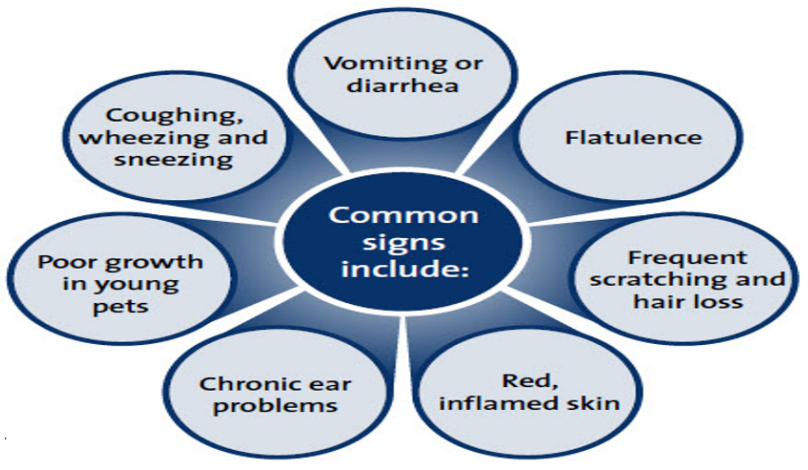

Figure 1

Herbal drugs treatment

Medicinal herbal drugs have gained importance and recognition in recent years as a result of their safety, effectuality and value effectiveness [23]. Many Indian healthful plants are extensively employed in the Indian ancient system of medication for the management of liver disorder (Table 3) [24-26]. Mono and poly-herbal preparations are employed in numerous diseases or disorders. In step with one estimate, quite 700 mono and poly-herbal preparations within the variety of simmering, tincture, tablets and capsules from quite 100 plants are in clinical use. In latest analysis it's have been investigate that drug-herbal combination treatment is various medication in market. Combination of various plant extracts as polyherbal medication is new approach in treatment of disease. Polyherbal formulation is employed wide by completely different prescription drugs corporations for treatment of liver toxicity (Table 4) [27,28]. A drug having useful impact on the liver is understood as hepatoprotective drug. On the opposite hand, medicine having harmful impact on the liver are higher called toxic medicine. Clinical analysis has conjointly shown that herbals have real utility within the treatment of liver diseases. These are generally classified into three categories without any strict delineation amongst them (Table 5) [29].

\begin{tabular}{|c|c|c|c|c|c|}
\hline S. No. & Scientific name & Common name & Family & Part used & Dose (Orally administered) \\
\hline 1 & Silymarine & Milk thistle & Asteraceae & Ripen seeds & $600-1200 \mathrm{mg} / \mathrm{kg}$ \\
\hline 2 & Andrographis & Bhuinimb & Acanthaeae & Leaves and tender shoot & $100-200 \mathrm{mg} / \mathrm{kg}$ \\
\hline 3 & Picrorhiza kurroa & kutki & Plantaginaceae & Dried rhizomes & $200 \mathrm{mg} / \mathrm{kg}$ \\
\hline 4 & Punarnava & Rakta punarnava & Nytaginaeae & Dried herb & $200-400 \mathrm{mg} / \mathrm{kg}$ \\
\hline 5 & Liquorcie & Jeshta madhu & Leguminosae & Dried rhizomes & $200-400 \mathrm{mg} / \mathrm{kg}$ \\
\hline 6 & Azadirachta indica & Neem & Meliaceae & Aerial parts & $100-200 \mathrm{mg} / \mathrm{kg}$ \\
\hline 7 & Curcuma longa & Haldi & Zingiberaceae & Rhizome & $100-200 \mathrm{mg} / \mathrm{kg}$ \\
\hline 8 & Eclipta alba & Bhringraj & Asteraceae & Leaves and flower & $200-400 \mathrm{mg} / \mathrm{kg}$ \\
\hline 9 & Fumaria officinalis & Earth smoke & Fumariaceae & Whole plant & $200-500 \mathrm{mg} / \mathrm{kg}$ \\
\hline 10 & Phyllanthus amarus & Bhuiamla & Euphorbiaceae & Whole plant & $100-200 \mathrm{mg} / \mathrm{kg}$ \\
\hline 11 & Phyllanthus niruri & Stonebreaker & Euphorbiaceae & Whole plant & $100-200 \mathrm{mg} / \mathrm{Kg}$ \\
\hline 12 & Phyllanthus embellica & Amla & Euphorbiaceae & Fruits & $100-200 \mathrm{mg} / \mathrm{Kg}$ \\
\hline 13 & Solanum nigrum & Black night shade & Solanaceae & Fruits & $100-200 \mathrm{mg} / \mathrm{Kg}$ \\
\hline 14 & Tinospora cordifolia & Gulvel & Mennispermaceae & Whole plant & $100-200 \mathrm{mg} / \mathrm{Kg}$ \\
\hline 15 & Uncaria gambir & Kattha & Rubiaceae & Leaves and shoots & $200-400 \mathrm{mg} / \mathrm{Kg}$ \\
\hline 16 & Withania somnifera & Ashwagandha & Solanaceae & Leaves & $100 \mathrm{mg} / \mathrm{kg}$ \\
\hline 17 & Ginkgo biloba & Maiden hair tree & Ginkgoaceae & Leaves and bark & $25-50 \mathrm{mg} / \mathrm{kg}$ \\
\hline 18 & Swertia chirata & Clearing nut & Gentianaceae & Whole plant & $100-200 \mathrm{mg} / \mathrm{Kg}$ \\
\hline 19 & Camellia sinensis & Tea plant & Theaceae & Seeds and leaves & $100-200 \mathrm{mg} / \mathrm{Kg}$ \\
\hline
\end{tabular}

Table 3: List of Indian traditional medicinal plants. 


\begin{tabular}{|c|c|c|c|c|}
\hline S. No. & Name of formulation & Plants used in formulation & Indication & Dose \\
\hline 1 & $\begin{array}{l}\text { Livokin (Herbo-med, } \\
\text { Kolkata) }\end{array}$ & $\begin{array}{l}\text { Andrographis paniculata, Apium graveolens, Ber- } \\
\text { beris lycium, Carum copticum, Cichorium intybus, } \\
\text { Cyperus rotundus, Eclipta alba, Ipomoea turpeth- } \\
\text { um, Oldenlandia corymbosa, Picrrorhiza kurroa, } \\
\text { Hygrophila spinosa, Plumbago zeylanica, Solanum } \\
\text { nigrum, Tephrosia purpurea, Terminalia arjuna, } \\
\text { Terminalia chebula, Trigonella foenumgraecum }\end{array}$ & $\begin{array}{l}\text { For hepatic } \\
\text { dysfunction }\end{array}$ & $\begin{array}{l}1-2 \text { teaspoon } 2 \\
\text { to } 3 \text { times daily }\end{array}$ \\
\hline 2 & $\begin{array}{l}\text { Tefroliv (TTK Pharma Pvt. } \\
\text { Ltd., Chennai) }\end{array}$ & $\begin{array}{c}\text { Andrographis paniculata, Eclipta alba, Ocimum } \\
\text { sanctum, Phyllanthus niruri, Picrrorhiza kurroa, } \\
\text { Piper longum, Solanum nigrum, Tephrosia purpurea, } \\
\text { Terminalia chebula }\end{array}$ & $\begin{array}{l}\text { Standardized liver for- } \\
\text { mulation for effective } \\
\text { hepatic regeneration }\end{array}$ & $\begin{array}{l}1 \text { teaspoon thrice } \\
\text { daily or as } \\
\text { directed by } \\
\text { physician }\end{array}$ \\
\hline 3 & $\begin{array}{l}\text { Octogen (Plethico Phar- } \\
\text { maceuticals Ltd., Indore) }\end{array}$ & Arogyavardhini rasa, Phyllanthus niruri & $\begin{array}{l}\text { Highly potent } \\
\text { hepatoprotective }\end{array}$ & $\begin{array}{l}\text { As directed by } \\
\text { physician }\end{array}$ \\
\hline 4 & $\begin{array}{l}\text { Stimuliv (Franco-Indian } \\
\text { Pharmaceuticals Pvt. Ltd., } \\
\text { Mumbai) }\end{array}$ & $\begin{array}{c}\text { Andrographis paniculata, Eclipta alba, Phyllanthus } \\
\text { niruri, Justicia procumbens }\end{array}$ & $\begin{array}{l}\text { Liver stimulant and } \\
\text { tonic }\end{array}$ & $\begin{array}{l}1 \text { - } 2 \text { teaspoon } 2 \\
\text { to } 3 \text { times daily }\end{array}$ \\
\hline 5 & $\begin{array}{c}\text { Liv } 52 \text { (Himalaya Drug Co, } \\
\text { Bangalore) }\end{array}$ & $\begin{array}{c}\text { Achillea millefolium, Capparis spinosa, Cassia } \\
\text { occidentalis, Cichorium intybus, Solanum nigrum, } \\
\text { Tamarix gallica, Terminalia arjuna }\end{array}$ & $\begin{array}{l}\text { Protects liver against } \\
\text { various hepatotoxins, } \\
\text { promote appetite and } \\
\text { growth }\end{array}$ & $\begin{array}{l}2-3 \text { teaspoon } 2 \\
\text { to } 3 \text { times daily }\end{array}$ \\
\hline 6 & $\begin{array}{c}\text { Livergen (Standard } \\
\text { Pharmaceuticals, } \\
\text { Serampore, West Bengal) }\end{array}$ & $\begin{array}{c}\text { Andrographis paniculata, Apium graveolens, } \\
\text { Asteracantha longifolia, Cassia angustifolia, } \\
\text { Trachyspermum ammi, Trigonella foenum graecum }\end{array}$ & $\begin{array}{l}\text { Gastrointestinal and } \\
\text { hepatic regulator }\end{array}$ & $\begin{array}{l}2 \text { - } 4 \text { teaspoon } \\
\text { twice daily }\end{array}$ \\
\hline
\end{tabular}

Table 4: List of six Polyherbal liquid formulations.

\begin{tabular}{|c|c|c|}
\hline S. No. & Agent & Explanation \\
\hline 1 & $\begin{array}{c}\text { Antihepatotoxic } \\
\text { agents }\end{array}$ & These generally antagonize the effects of any hepatotoxins causing hepatitis or any liver disease. \\
\hline 2 & Hepatotropic agents & $\begin{array}{r}\text { These generally support or promote the healing process of the liver. In practice these two } \\
\text { activities cannot be easily distinguished from each other. }\end{array}$ \\
\hline 3 & $\begin{array}{c}\text { Hepatoprotective } \\
\text { agents }\end{array}$ & $\begin{array}{r}\text { These generally prevent various types of liver affections prophylactically. In general, any } \\
\text { hepatoprotective agent can act as an antihepatotoxic or hepatotropic agent but the vice versa is } \\
\text { always not true. }\end{array}$ \\
\hline
\end{tabular}

\section{Table 5}

\section{Conclusion}

Chronic Liver diseases stand jointly of the foremost health troubles worldwide, with liver disease and drug iatrogenic liver injury accounting $9^{\text {th }}$ leading reason behind death in developing countries. Many healthful plants area unit currently prevailing for the treatment of assorted liver diseases. Most of them area unit potential hepatogenic/hepatoprotective against hepatotoxicity.
Healthful plants claimed as liver protecting agent's area unit classified in keeping with their biological supply, Phytoconstituents half used and plants in formulations. Individuals from India area unit still hooked in to standard therapies to treat liver complications. As a result of their straightforward convenience and low value. Since massive mass of populations used preferred seasoning preparation, so there's have to be compelled to be 
assess for his or her proportion, their dose and rational behind combination in numerous polyherbal formulations. This review concentrates on reason behind hepatotoxicity by numerous cyanogenic compounds and their cure by seasoning medication and polyherbal formulations. For the long run prospect, screening of crude plant extracts and isolation of active hepatoprotective phytochemical compounds will increase risk in unwellness treatment and cure.

\section{Acknowledgement}

Authors would like to thanks to Mr. Jivan Kumar; Production officer of Kusum Healthcare Pvt. Ltd. Chopanki, Bhiwadi (Rajasthan) India, for her support and helpful in cooperation in the review and data collection process.

\section{Conflict of Interest}

The Authors declare that there is no conflict of interest.

\section{Bibliography}

1. Poilil SS., et al. "Nanoparticles for the treatment of liver fibrosis". International Journal of Nanomedicine 12 (2017): $6997-$ 7006.

2. Girish C., et al. "Herbal drugs on the liver". Liver Pathophysiology: Therapies and Antioxidants. Waltham, MA: Elsevier (2017): 605-620.

3. Abenavoli L., et al. "Silymarin for liver disease". Liver Pathophysiology: Therapies and Antioxidants. Waltham, MA: Elsevier (2017): 621-631.

4. Hernández-Aquino E., et al. "Naringenin and the liver". Liver Pathophysiology: Therapies and Antioxidants. Waltham, MA: Elsevier (2017): 633-651.

5. Vázquez-Flores LF., et al. "Antioxidant anti-inflammatory and antifibrotic properties of quercetin in the liver". Liver Pathophysiology: Therapies and Antioxidants. Waltham, MA: Elsevier (2017): 653-674.

6. Arauz J., et al. "Coffee and the liver". Liver Pathophysiology: Therapies and Antioxidants. Waltham, MA: Elsevier (2017): 675-685.

7. Reyes-Gordillo K., et al. "Hepatoprotective properties of curcumin. Liver pathophysiology: Therapies and Antioxidants. Waltham, MA: Elsevier (2017): 687-704.
8. Ramos-Tovar E and Muriel P. "Stevia as a putative hepatoprotector". Liver Pathophysiology: Therapies and Antioxidants. Waltham, MA: Elsevier (2017): 715-727.

9. Wang K., et al. "Naringenin reduces oxidative stress and improves mitochondrial dysfunction via activation of the Nrf2/ ARE signaling pathway in neurons". International Journal of Molecular Medicine 40.5 (2017): 1582-1590.

10. Ali R., et al. "Amelioration of benzo[a]pyrene-induced oxidative stress and pulmonary toxicity by naringenin in Wistar rats: a plausible role of COX-2 and NF-кB". Human and Experimental Toxicology 36.4 (2017): 349-364.

11. Blach S., et al. "Global prevalence and genotype distribution of hepatitis C virus infection in 2015: a modelling study". The Lancet Gastroenterology and Hepatology 2.3 (2017): 161-176.

12. Liu Z., et al. "The epidemiology of hepatitis B and hepatitis $C$ infections in China from 2004 to 2014: an observational population-based study." Journal of Viral Hepatitis 25.12 (2018): 1543-1554.

13. Konerman MA., et al. "Impact of an electronic health record alert in primary care on increasing hepatitis c screening and curative treatment for baby boomers". Hepatology 66.6 (2017): 1805-1813.

14. lee BP., et al. "Outcomes of early liver transplantation for patients with severe alcoholic hepatitis". Gastroenterology 155.2 (2018): 422-430.

15. Vergis N., et al. "In patients with severe alcoholic hepatitis, prednisolone increases susceptibility to infection and infection-related mortality, and is associated with high circulating levels of bacterial DNA". Gastroenterology 152.5 (2017): 10681077.

16. Duvoor C., et al. "A day-4 Lille model predicts response to corticosteroids and mortality in severe alcoholic hepatitis". The American Journal of Gastroenterology 112.2 (2017): 306-315.

17. Wong MCS., et al. "International incidence and mortality trends of liver cancer: A global profile". Scientific Reports 7 (2017): 45846.

18. Forner A., et al. "Hepatocellular carcinoma”. Lancet 391.10127 (2018): 1301-1314. 
19. Fateen W., et al. "Screening for hepatocellular carcinoma: patient selection and perspectives". Journal of Hepatocellular Carcinoma 4 (2017): 71-79.

20. Younes R., et al. "Should we undertake surveillance for HCC in patients with NAFLD?" Journal of Hepatology 68.2 (2018): 326-334.

21. Heimbach JK., et al. "AASLD guidelines for the treatment of hepatocellular carcinoma". Hepatology 67.1 (2017): 358-380.

22. Bruix J., et al. "Regorafenib for patients with hepatocellular carcinoma who progressed on sorafenib treatment (RESORCE): A randomised, double-blind, placebo-controlled, phase 3 trial". Lancet 389.10064 (2017): 56-66.

23. Kudo M., et al. "Lenvatinib versus sorafenib in first-line treatment of patients with unresectable hepatocellular carcinoma: A randomised phase 3 non-inferiority trial". Lancet 391.10126 (2018): 1163-1173.

24. Cholankeril G., et al. "Alcoholic liver disease replaces hepatitis $\mathrm{C}$ virus infection as the leading indication for liver transplantation in the United States". Clinical Gastroenterology and Hepatology 16.8 (2018): 1356-1358.

25. Ramon B., et al. "Current Trends in Alcohol-Related Liver Disease”. Journal of Hepatology 70.2 (2019): 221-334.

26. Younossi Z., et al. "Global burden of NAFLD and NASH: trends, predictions, risk factors and prevention". Nature Reviews Gastroenterology and Hepatology 15.1 (2018): 11-20.
27. Chan WK., et al. "Asia-Pacific Working Party on Non-alcoholic Fatty Liver Disease guidelines 2017 - Part 1: definition, risk factors and assessment". Journal of Gastroenterology and Hepatology 33.1 (2018): 70-85.

28. Chitturi S., et al. "The Asia-Pacific Working Party on Non-alcoholic Fatty Liver Disease guidelines 2017-Part 2: Management and special groups". Journal of Gastroenterology and Hepatology 33.1 (2018): 86-98.

29. Chalasani N., et al. "The diagnosis and management of nonalcoholic fatty liver disease: practice guidance from the American Association for the Study of Liver Diseases". Hepatology 67.1 (2018): 328-357.

Volume 3 Issue 7 July 2019

(c) All rights are reserved by Saurabh Nimesh and Shubham. 